\title{
Sprawozdanie z międzynarodowej konferencji naukowej „Wyzwania polityki bezpieczeństwa. Historia i współczesność", Lwów, 18-19 października 2018 r.
}

W drugiej połowie października w kompleksie dydaktycznym Narodowej Akademii Wojsk Lądowych im. Hetmana Piotra Sahajdacznego we Lwowie odbyła się kolejna konferencja poświęcona szeroko rozumianym zagadnieniom polityki bezpieczeństwa. Konferencje o tej tematyce mają już swoją tradycję. Od co najmniej pięciu lat odbywają się naprzemiennie we Lwowie oraz w Rzeszowie, na Uniwersytecie Rzeszowskim. Obie uczelnie od lat współpracują na polu naukowym, organizując wspólne przedsięwzięcia z zakresu bezpieczeństwa oraz historii, głównie wojskowej.

Konferencja cieszyła się ogromnym zainteresowaniem, zgromadziła ponad stu uczestników, w tym niemal 50 prelegentów z Polski i Ukrainy. Składała się z dwóch części. Obrady rozpoczęły się od części oficjalnej, w której jako pierwszy głos zabrał komendant-rektor gen. prof. Pawło Tkaczuk, witając przybyłych gości. Następnie przemawiali przedstawiciel Prezydenta Ukrainy Wasilij Pawłow, konsul RP we Lwowie Rafał Wolski, na końcu w imieniu polskiej delegacji uczestników przywitał dr hab. prof. UR Andrzej Bonusiak.

Po części oficjalnej rozpoczęły się obrady plenarne. Wygłoszono cztery referaty. Prof. B. Leczuk analizował miejsce Ukrainy w nowoczesnej architekturze bezpieczeństwa europejskiego. Prof. E. Mazda przedstawił aktualne wyzwania związane z hybrydową agresją Rosji. Jako trzeci zabrał głos prof. H. Ćwięk, który skoncentrował się na roli dyplomacji w służbie państwu na przykładzie relacji Polski z Niemcami.

${ }^{1}$ Dr Paweł Korzeniowski, Instytut Historii Uniwersytetu Rzeszowskiego, al. Rejtana 16c, 35-959 Rzeszów, e-mail: korzeniowski.p@gmail.com 
Prof. O. Demianiuk omówił zagadnienie wywiadu zewnętrznego w dobie rewolucji ukraińskiej.

Pierwszego dnia obradowały dwie sekcje tematyczne. Sekcja pierwsza, której przewodniczył prof. A. Kharuk, obejmowała zagadnienia związane $\mathrm{z}$ międzynarodowym systemem bezpieczeństwa. W trakcie obrad wygłoszono osiem referatów skupionych wokół następującej problematyki: wyzwań dla ukraińskiej i międzynarodowej polityki; agresji wojskowej przeciwko Ukrainie; aktualnych problemów walki z terroryzmem; zjawiska tzw. „wojny hybrydowej”; wyzwań dla międzynarodowego bezpieczeństwa w związku z wojną w Syrii; bezpieczeństwa energetycznego i informatycznego.

Sekcja druga, obradująca pod kierownictwem prof. I. Soljara, skoncentrowała się na kwestiach związanych z bezpieczeństwem militarnym, ze szczególnym uwzględnieniem zagrożeń hybrydowych. W jej trakcie wygłoszono 10 referatów, poświęconych m.in. rosyjsko-ukraińskiemu konfliktowi zbrojnemu, kwestii mniejszości polskiej zamieszkującej strefę działań zbrojnych, ewolucji walki zbrojnej, ideologicznej reintegracji terytorium czasowo okupowanego przez siły prorosyjskie, bezpieczeństwu militarnemu w aspekcie prawno-ustrojowym, wyzwaniom militarnego bezpieczeństwa na Morzu Azowskim, a także praktycznemu stosowaniu doktryny wojny hybrydowej w nawiązaniu do konfliktu rosyjsko-ukraińskiego.

Dwie kolejne sekcje obradowały drugiego dnia konferencji. W sekcji 3, pod przewodnictwem dr. doc. O. Kuczka, omawiano problematykę pozamilitarnych aspektów bezpieczeństwa. Także na niej wygłoszono 10 referatów. Dyskusja koncentrowała się na kwestiach związanych m.in. z: ekologicznymi aspektami bezpieczeństwa, szkoleniu funkcjonariuszy systemu bezpieczeństwa państwa, nieuczciwych praktykach rynkowym i ich wpływie na bezpieczeństwo konsumenta, kryzysie migracyjnym w Europie, bezpieczeństwie energetycznym oraz ekonomicznym.

Ostatnia sekcja, której przewodniczył dr doc. W. Buzdruk, obradowała nad zagadnieniami związanymi z historycznymi aspektami polityki bezpieczeństwa. Dziesięć wystąpień dotyczyło bardzo szerokiej tematy$\mathrm{ki}$, w tym m.in. uzbrojenia formacji kozackich na przełomie IX i XX wieku, kampanii gallipolijskiej z 1915 roku, brytyjskich działań w Omanie w latach 1985, 1970-75, relacji i wspomnień z tzw. Wielkiego Głodu, historii wojsk kolejowych na Ukrainie, amerykańskich koncepcji związanych z periodyzacją „zimnej wojny”, udziałowi wolontariuszy w konflikcie rosyjsko-ukraińskim oraz działalności dydaktycznej Narodowej Akademii Wojsk Lądowych. 
Oprócz wymiaru naukowego konferencja stanowiła doskonałą okazję do poznania i nawiązania osobistych relacji badaczy z Polski i Ukrainy. Sprzyjała im uroczysta kolacja zorganizowana po pierwszym dniu obrad. Drugiego dnia, już po oficjalnym zakończeniu konferencji, uczestnicy zwiedzali muzeum akademii i zapoznali się z jego historią. Po południu natomiast polska delegacja zwiedzała starówkę miasta, podziwiając perły architektury, m.in. słynną lwowską operę. 